\title{
MENINGKATKAN PENGETAHUAN SISWA MELALUI PEMANFAATAN LINGKUNGAN SEKOLAH SEBAGAI MEDIA PEMBELAJARAN PADA SISWA KELAS II SDN 2 TEMBENG PUTIK TAHUN AJARAN 2019/2020
}

\author{
Yuniar lestarini, M.Pd, Universitas Hamzanwadi \\ Indra Himayatul Asri, M.Pd, Universitas Hamzanwadi \\ Muhammad Husni,M.Pd, Universitas Hamzanwadi \\ yuniarlestarini1@gmail.com, zulkarnainindra97@gmail.com, \\ muhammad.husni2014@gmail.com
}

\begin{abstract}
Abstrak
Penelitian ini bertujuan untuk mengetahui bagaimana meningkatkan pengetahun siswa dengan memanfaatkan lingkungan sekolah sebagai media pembelajaran pada siswa kelas II SDN 2 Tembeng Putik. Penelitian ini adalah Penelitian Tindakan Kelas(PTK).PenelitianTindakan Kelas ini dilakukan dalam dua siklus dimana tiap-tiap siklus terdiri dar iempat tahap yaitu tahap perencanaan, pelaksanaan, observasi, evaluasi dan refleksi. Dengan subyek penelitian siswa kelasll tahun pelajaran 2019/2020, yang terdiri dari 23 siswa. Hasil penelitian ini menunjuk kan bahwa terdapat peningkatan pengetahuan siswa dari siklus kesiklus. Rata-rata hasil pengetahuan siswa untuk siklus I sebesar 66,96 dengan persentase ketuntasan 53,13\% dan pada siklus II sebesar 81.30 dengan persentase ketuntasan $87,50 \%$. Dengan memperhatikan hasil yang di peroleh maka peningkatan pengetauan siswa telah tercapai. Dengan demikian, dapat diambil suatu kesimpulan bahwa melalui pemanfaatan lingkungan sekolah sebagai media pembelajaran dapat meningkatkan pengetahuan siswa kelas II SDN 2 Tembeng Putik tahun pelajaran 2019/2020.
\end{abstract}

Kata Kunci :Meningkatkan Pengetahuan, Pemanfaatan Lingkungan Sekolah

\section{PENDAHULUAN}

\section{Latar Belakang}

Pembelajaran Kurikulum 2013
berorientasi kepada usaha-usaha
penyiapan lahirnya generasi emas
Indonesia 2045 yang didambakan.
Generasi Indonesia yang memiliki
kompetensi yaitu seperangkat sikap,

pengetahuan dan keterampilan yang harus dimiliki, dihayati dan dikuasai oleh siswa setelah mempelajari suatu muatan pembelajaran. Proses pembelajaran kurikulum 2013 memberikan kesempatan kepada siswa untuk mengembangkan potensinya menjadi kemampuan yang semakin lama semakin meningkat dalam 
sikap, pengetahuan dan keterampilan yang diperlukan dirinya untuk hidup dan untuk bermasyarakat, berbangsa serta berkontribusi pada kesejahteraan hidup umat manusia (Permendikbud No. 104 tahun 2014 tentang pembelajaran). Pendidikan di tingkat dasar adalah fondasi pembentukan manusia seutuhnya sehingga membutuhkan sistem pendidikan yang komprehensif. Mendidik anak SD pada hakikatnya tidak hanya membekali dengan penjelasan secara verbal saja tetapi penting diikuti dengan praktik langsung. Materi belajar hendaknya tidak hanya bersumber dari bukuteks saja, namun diperkaya dengan memanfaatkan media pembelajaran salah satunya memanfaatkan lingkungan sekolah. Dari observasi awal yang peneliti lakukan khususnya pada proses kegiatan belajar mengajar guru lebih fokus pada pembelajaran di dalam kelas dan kurang memanfaatkan lingkungan di luar kelas. Padahal dari segi potensi lingkungan sekolah dengan suasana alam pedesaan sangat mendukung untuk dijadikan sebagai alternatif dalam memberikan variasi belajar yang dapat membantu siswa dalam meningkatkan pengetahuannya tentang materi pembelajaran. Potensi lingkungan sekolah yang sangat mendukung tentunya sangat efektif digunakan jika guru mampu memanfaatkannya dengan kreatif. Disamping itu memanfaatkan lingkungan sekolah dapat memperkaya strategi mengajar guru. (Ario Sutarto IDIK 4403 : 6). Atas dasar inilah peneliti tertarik melakukan penelitian dengan judulMeningkatkan Pengetahuan Siswa Melalui Pemanfaatan Lingkungan Sekolah Sebagai Media Pembelajaran Pada Siswa Kelas II SDN 2 Tembeng Putik Tahun Ajaran 2019/2020.

\section{Identifikasi Masalah}

\section{Berdasarkanlatarbelakang}

diatas maka dapat diidentifikasi permasalahan, yaitu:

1. Siswa merasa bosan dalam mengikuti proses belajar yang hanya terpaku di dalam kelas dan monoton

2. Guru kurang memanfaatkan lingkungan sekolah sebagai media pembelajaran

\section{Pembatasan Masalah}

Melihat banyaknya faktor di atas dan luasnya sasaran penelitian serta penelitian ini tidak dapat mengidentifikasi semua masalah diatas dengan tuntas, mengingat pertimbangan waktu, biaya, dan kemampuan penelitian, maka masalah tersebut di batasi pada :

1. ObyekPenelitian

Obyek penelitian ini adalah Meningkatkan Pengetahuan Siswa Melalui Pemanfaatan Lingkungan Sekolah Sebagai Media Pembelajaran. Dalam hal ini lebih 
difokuskan pada materi ajar tema 6, subtema 4 (Merawat Tumbuhan).

2. SubyekPenelitian Subyek penelitian ini terbatas pada siswa kelas II SDN 2 Tembeng Putik Tahun Ajaran 2019/2020.

\section{Rumusan Masalah}

Berdasarkan Identifikasi dan pembatasan masalah di atas, maka dapat dirumuskan permasalahan sebagai berikut: Apakah Pemanfaatan Lingkungan Sekolah Sebagai Media Pembelajaran Dapat Meningkatkan Pengetahuan Pada Siswa Kelas II SDN 2 Tembeng Putik Tahun Ajaran 2019/2020.

\section{Tujuan Penelitian}

Adapun tujuan yang ingin dicapai dalam penelitian ini adalah, untuk mengetahui Apakah Pemanfaatan Lingkungan Sekolah Sebagai Media Pembelajaran Dapat Meningkatkan Pengetahuan Pada Siswa Kelas II SDN 2 Tembeng Putik Tahun Ajaran 2019/2020.

\section{ManfaatPenelitian}

Penelitian yang dilakukan ini diharapkan bermanfaat secara teoritis dan praktis, yaitu sebagai berikut :

1. Manfaat secarateoritis

Hasil penelitian ini diharapkan dapat memberikan dorongan dan motivasi kepada para peneliti lain untuk melakukan penelitian lanjutan yang lebih luas dan mendalam serta berusaha untuk mengungkapkan dan menemukan faktor-faktor lain.

2. Manfaat secara praktis

a. Hasil penelitian ini diharapkan dapat dimanfaatkan bagi kepala sekolah tempat mengadakan penelitian untuk dijadikan bahan acuan guna memberikan pembinaan terhadap guru.

b. Penelitian ini juga diharapkan dapat meningkatkan pengetahuan siswa sehingga dapat memperoleh hasil yang diharapkan.

\section{METODE PENELITIAN}

Penelitian ini merupakan Penelitian Tindakan yang bertujuan untuk Meningkatkan Pengetahuan Siswa Melalui Pemanfaatan Lingkungan Sekolah Sebagai Media Pembelajaran Pada Siswa Kelas II SDN 2 Tembeng Putik Tahun Ajaran 2019/2020. Rancangan penelitian yang digunakan adalah rancangan model Kemmis yang terdiri atas empat langkah, yakni: perencanaan, pelaksanaan, observasi dan refleksi (Sukardi, 2005:45). Subjek dalam penelitian ini adalah siswa kelas II SDN 2 Tembeng Putik Tahun Ajaran 2019/2020 yang berjumlah 23 orang siswa.

Teknik pengumpulan data yang digunakan dalam penelitian ini dengan cara observasi. Instrumen yang digunakan untuk melaksanakan penelitian adalah (1) dokumen observasi tindakan 
berupa catatan terhadap siswa selama pembelajaran berlangsung, dokumen tindakan analisis setiap akhir siklus, (2) sumber informasi lain adalah kolaborator (guru) yang mengamati selama pelaksanaan tindakan, (3) lembaran test berupa soal yang digunakan untuk melihat peningkatan pengetahuan siswa tentang materi merawat tumbuhanyang sudah diajarkan.

Data yang diperoleh dianalisis dan dideskripsikan dalam bentuk laporan hasil penelitian dengan menggunakan analisis deskriptif sederhana dengan menghitung persentase peningkatan pengetahuan siswa.

\section{HASIL DAN PEMBAHASAN}

Penelitian tindakan kelas (PTK) ini dilakukan untuk meningkatkan pengetahuan siswa dengan memanfaatkan lingkungan sekolah sebagai media pembelajarannya. Penelitian dilakukan dengan 2 siklus karena pada siklus 1 belum tuntas sehingga dilanjutkan ke siklus 2. Berikut ini dipaparkan analisis data tiap-tiapsiklus

Ringkasan hasil belajar siswa siklus I

\begin{tabular}{|c|c|c|c|l|l|l|}
\hline $\begin{array}{l}\text { Jumlah } \\
\text { siswa }\end{array}$ & $\begin{array}{l}\text { Total } \\
\text { nilai }\end{array}$ & $\begin{array}{l}\text { Nilai } \\
\text { rata-rata }\end{array}$ & $\begin{array}{l}\text { Jumlah } \\
\text { siswa } \\
\text { tuntas }\end{array}$ & $\begin{array}{l}\text { Jumlah } \\
\text { siswa tidak } \\
\text { tuntas }\end{array}$ & $\begin{array}{l}\text { Persentas } \\
\text { e } \\
\text { ketuntasa } \\
\text { n klasikal }\end{array}$ & keterangan \\
\hline 23 & 1540 & 66.96 & 13 & 10 & $53.13 \%$ & Belum tuntas \\
\hline
\end{tabular}

Berdasarkan tabel dapat dilihat bahwa dari 23 siswa yang mengikuti pembelajaran terdapat 13 siswa yang tuntas dengan nilai rata-rata keseluruhan 66,96 dan tidak tuntas sebanyak 10 orang sehingga persentase ketuntasan belajar siklus I ini adalah 53.13\%, ini menunjukkan bahwa masih kurang dari $85 \%$. pada pelaksanaan siklus I belum mencapai ketuntasan belajar, dengan demikian perlu ditingkatkan pada siklus selanjutnya atau pada siklus II.

Tabel ringkasan hasil belajar siswa siklus II

\begin{tabular}{|c|c|c|c|c|l|l|}
\hline $\begin{array}{l}\text { Jumlah } \\
\text { siswa }\end{array}$ & $\begin{array}{l}\text { Total } \\
\text { nilai }\end{array}$ & $\begin{array}{l}\text { Nilai } \\
\text { rata- } \\
\text { rata }\end{array}$ & $\begin{array}{l}\text { Banyak } \\
\text { siswa } \\
\text { tuntas }\end{array}$ & $\begin{array}{l}\text { Banyak } \\
\text { siswa } \\
\text { tidak } \\
\text { tuntas }\end{array}$ & $\begin{array}{l}\text { Persentas } \\
\text { ketuntasa } \\
n\end{array}$ & $\begin{array}{l}\text { keteranga } \\
n\end{array}$ \\
\hline 23 & 1870 & 81.30 & 20 & 3 & $87.50 \%$ & Tuntas \\
\hline
\end{tabular}


Jadi berdasarkan tabel ringkasan hasil pengetahuan siswa siklus II di atas menujukan bahwa telah tercapai target ketuntasan belajar yang telah ditetapkan oleh kurikulum sehingga untuk siklus selanjutnya diberhentikan sampai siklus II ini.

Berdasarkan hasil penelitian pada tiap-tiap siklus, menunjukan bahwa hasil dari siklus I ke siklus II mengalami peningkatan. Pada siklus I menunjukan bahwa nilai rata-rata kelas sebesar 66.96 dengan persentase ketuntasan $53.13 \%$ ini menunjukan bahwa hasil pengetahuan siswa belum tuntas. Hal ini disebabkan karena siswa belum berani menjawab pertanyaan guru, antar siswa masih kurang mau berkerjasama, sehingga dalam peroses belajar mengajar masih sangat kurang aktif dalam proses pembelajaran, ditambah lagi dengan kurangnya keberanian siswa untuk bertanya kepada temannya yang pandai maupun pada teman yang lainnya, kurangnya keberanian siswa menjawab pertanyaan yang dilemparkan oleh guru.

Untuk mengatasi hal tersebut guru melakukan perbaikan-perbaikan dalam peroses belajar mengajar serta meningkatkan hal-hal yang masih dianggap kurang. Dari persentase hasil belajar siswa dan aktivitas belajar siswa dalam peroses pembelajaran belum mencapai target yang ditetapkan oleh kurikulum. Oleh karena itu perlu adanya perbaikan pada siklus II.

Pada siklus II guru melakukan penyempurnaan dan perbaikan-perbaikan pada siklus I dengan memberikan perbaikan-perbaikan diantaranya adalah sebagai berikut: guru menuntun atau memilih tutor sebaya untuk tiap-tiap kelompok untuk membantu/mengajari temannya yang belum paham tentang materi yang dipelajari dan guru menekankan kepada siswa bahwa sutau kelompok di katakan berhasil jika tiap-tiap kelompok paham tentang materi yang dipelajari dan bisa menjawab pertanyaan yang dilemparkan guru dengan benar. guru memotivasi siswa untuk lebih berani dan tidak malu-malu untuk berbicara didepan kelas dan tidak malu-malu untuk bertanya kepada guru maupun temanya, guru menekankan pada siswa bahwa tiap kelompok yang maju menjelaskan harus memiliki keberanian berbicara didepan kelas agar anggota kelompoknya paham dan anggota kelompok yang lainnya juga paham. Pada siklus II ini guru memfokuskan pada pemberian perhatian untuk semua anggota kelompok dan lebih meningkatkan pada cara membimbing siswa dalam peroses pembelajaran.

Berdasarkan hasil analisis data pada siklus II menunjukan bahwa rata-rata nilai kelas sebesar 81.30 dengan nilai terendah 55 dan nilai tertinggi sebesar 95 dengan persentase ketuntasan hasil 
belajar siswa adalah $87.50 \%$ hal ini menunjukan bahwa hasil belajar siswa tuntas.

\section{KESIMPULAN}

Dengan memanfaatkan lingkungan sekolah sebagai media pembelajaran ternyata mampu meningkatkan pengetahuan siswa. Hal ini dapat dibuktikan dengan hasil analisis data, di mana pada siklus I mempunya inilai ketuntasan $53.13 \%$ dengan nilai rata-rata 66.96 sedangkan pada siklus II mengalami peningkatan dengan nilai ketuntasan $87.50 \%$ dengan nilai rata-rata 81.30. Hal ini disebabkan karena siswa terlibat langsung dalam melakukan pengamatan dan mencari informasi sendiri tentang materi pembelajaran yang diberikan dan hal tersebut tentunya akan membuat siswa lebih cepat untuk mengerti dan mengingatnya, sehingga sebagian besar siswa mampu menjawab soal dengan benar. Selain itu pada proses pembelajaran siswa berhubungan langsung dengan lingkungan sekolah sebagai media pembelajaran sehingga ingatan siswa terhadap materi pembelajaran yang diberikan menjadi kuat dan bermakna.

Hasil penelitian menunjukkan bahwa terdapat Peningkatkan Pengetahuan Siswa Melalui Pemanfaatan Lingkungan Sekolah Sebagai Media Pembelajaran Pada Siswa Kelas II SDN 2 Tembeng Putik Tahun Ajaran 2019/2020. Berdasarkan hasil penelitian, bahwa skor rata-rata sebelum dilakukan tindakan adalah 57,69 dengan kategori rendah dimana dari 23 siswa hanya 7orang yang mencapai KKM. Sedangkan pada akhir siklus 1 terdapat peningkatan dengan rata-rata 68,46 dimana 11 siswa yang memiliki nilai dibawah 70 dan siklus II ternyata dari 23 siswa, hanya 1orang siswa $(3,85 \%)$ yang memperoleh nilai dibawah 70 dimana skor terendah 65 dan tertinggi 100 dengan nilai rata-rata 79,75 .

\section{DAFTAR PUSTAKA}

Arikunto, Suharsimi. 2012. Dasar-DasarEvaluasiPendidikan. Jakarta: BumiAksara

Darmadi, Hamid. 2011. MetodePenelitianPendidikan. Bandung: Alfabeta

Fathurrohman, Pupuh. 2014. Strategibelajarmengajar. PT RefikaAditama: Bandung.

Ismawati,Siti.2014.Pemanfaatan Lingkungan Sebagai Sumber Belajar Untuk Meningkatkan Keterampilan Menulis Laporan Pengamatan. Jurnal Universitas Negeri Surabaya PGSD FKIP. Vol. 02 NO. 02. (On Line) Tersedia: http://Jurnal.Uns.ac.id /index.php/CP/erticle/download/335315 (10 Januari 2018). 
Pratiwi.A. 2012.Keterampilan proses dan model pembelajaran inkuiri terbimbing.(On line).Tersedia: http://repository.upi.edu/operator/, (10 Januari 2018).

Supardi. 2011.Media Pembelajaran. Yogyakarta: Kurnia alam semesta. 